\title{
A new direction for public health in England:
}

\author{
few devils, few details
}

A quarter of a century ago, the Acheson Report ${ }^{1}$ helped to address the challenges of a public health system perceived to be unsuitable in the wake of policy failures, concerns over communicable disease control, an imminent NHS reorganisation, a demoralised public health workforce, and uncertainty over how to meet the challenges of commissioning. Can Healthy Lives, Healthy People deal with many of the same challenges today? ${ }^{2}$

Public health professionals awaited the coalition government's public health White Paper with nervous apprehension. Their detachment from the White Paper's development was underlined by private sector involvement in shaping public health policy. Nevertheless, this government has not shelved the Marmot review (Fair Society, Healthy Lives) in the manner of their predecessor's response to the Black Report a generation earlier. Rather it has billed this White Paper as a response to Marmot's work and adopted its life course framework for tackling the wider social determinants of health. ${ }^{3}$ Can this government use such expertise to address health inequalities where the last government is widely perceived to have failed? ${ }^{4}$

Healthy Lives, Healthy People is a perplexing amalgam. Much of the document covers familiar ground describing health and wellbeing today and opportunities for major advances. GPs need no reminding of how unequally health-determining opportunities are distributed or how improvements to child public health and educational attainment could reduce later risks of physical and mental illness. The costs of many lost opportunities are carefully detailed. We could, for example, save up to $£ 100$ billion a year by reducing working-age ill health. ${ }^{5}$

\section{HOW IT WILL WORK}

The coalition aims to build self-esteem and resilience from infancy with stronger support for early years, and central to delivering this huge agenda is supposed to be a new, 'localised' public health system. Directors of public health, the strategic leaders for addressing health inequalities, are returning to the local authorities from whence they originally evolved. (The first Medical Officers of Health began discharging their responsibilities from municipalities in the middle of the 19th century.) This places directors of public health closer to those responsible for upstream influences on health; for example, housing, transport, leisure, and the environment.

They will be supported by Public Health England, a dedicated, new service set up as part of the Department of Health to strengthen emergency preparedness and health protection. Ring-fenced funding of over £4 billion is to ensure against cost pressures both centrally and in local authorities. A new 'health premium' will reward them for progress against elements of a public health outcomes framework which will take health inequalities into account. The best evidence in support of innovative approaches to behaviour change will be compiled by a new National Institute for Health Research School for Public Health Research and a Behaviour and Health Research Unit.

The centralisation of expertise should allow for more coordinated action on truly national issues, as well as for less duplication of effort. Such proximity to government will bring challenges. Restrictions on tobacco display and plain cigarette packs are both mentioned but it will take considerable strength to articulate the case for such measures in the face of fierce political lobbying from industries with vast resources at their disposal. Beyond the structural changes, other strategic shifts are apparent. For example, the value of mass media for promoting public health messages is downplayed. Although it can be difficult to demonstrate the role of mass media messages in shifting social norms, such programmes have been instrumental to many important public health gains. ${ }^{6}$

How will the new public health service work in practice? Frequent references to 'documents forthcoming' accentuate a sense that these proposals are being developed on the hoof. Some tensions are evident. For a working partnership with the $\mathrm{NHS}$, directors of public health will need the resources and support to build up a critical mass in skilled teams. To be effective they will also require sufficient autonomy to avoid being ensnared in council politics. Financial stringencies across local government are bound to place pressures on public health, and the scope of such budgets will be key. Whose budget, for example, will provide for road safety?

\section{COMMISSIONING CHALLENGES}

The commissioning function of primary care trusts (PCTs) will pass to practice consortia. Their numbers are likely to be more than double the present number of PCTs. This proliferation of commissioners rapidly making new contractual arrangements risks inefficiency. (In the US, transaction costs account for around 15\% of all money spent on health care. ${ }^{7}$ ) Conflicts of interest, as providers become commissioners, will be rife and another challenge will be to ensure open competition where appropriate. In the absence of PCTs as a buffer, consortia will need to develop robust mechanisms for dealing with information and demands from the centre. GPs will have new opportunities to respond to the needs that they identify among their populations; less welcome will be the uncomfortable 
responsibilities for managing patient demand - or rationing.

The challenges for GP commissioning are becoming clearer, but the nature of the assistance that will be available remains opaque. Public health teams have supplied GPs with epidemiological analyses and practical support in the past. The relationships and systems facilitating this have grown with time and perseverance. As these relationships fray, the private sector is already offering its support. Consortia will need to see past the presentational gloss and get the best deal for their population. Some public health practitioners are likely to establish bodies for the provision of commissioning assistance but this workforce is in limited supply and faces an uncertain future.

\section{THE ROLE OF GPS}

The White Paper leaves public health specialists awaiting more detail but offers GPs opportunities for an extended public health role, beyond individual behaviour change and chronic disease management. Tomorrow's GPs will be expected to respond, not simply to the presenting patient, but to their communities as a whole. GPs with leadership skills and a broader community orientation will be essential for the new consortia, and training will be needed to develop such individuals. Whether this will bring us closer to Julian Tudor Hart's 'new kind of doctor' - a community GP engaged in local participatory democracy to maximise the population's health - remains to be seen. ${ }^{8}$ The commitment of $£ 577$ million to training an extra 4200 health visitors is a reminder that public health in primary care is other people's business too.

\section{ADDRESSING HEALTH INEQUALITIES}

Most attention in general practice has understandably focused on the new government's implausibly ambitious commissioning proposals. Evidence rather than ideology suggests they will disappoint. Encouraging private provision may exacerbate the inverse care law and undermine efficiency gains. Moving commissioning responsibilities from bodies responsible for whole populations in defined geographical areas to amorphous consortia with responsibilities for registered patients only, may compromise equity objectives. ${ }^{9}$ Ringfencing NHS budgets in the context of cuts to social welfare and other areas of public expenditure is unlikely to further public health. ${ }^{10}$

These reforms may become mired, but the poor are always with us. As general practices begin to grapple with different ways of working, we will be well served if directors of public health in their new roles can improve on the lamentable record of previous governments in addressing health inequalities.

\section{Steve Gillam,}

GP, Lea Vale Medical Group, Luton.

\section{Amir Shroufi,}

Specialist Registrar in Public Health, Department of Public Health \& Primary Care, Institute of Public Health, University of Cambridge, Cambridge.

\section{Provenance}

Commissioned, not externally peer reviewed.

\section{REFERENCES}

1. Acheson D. (Chairman) Independent inquiry into inequalities in health (the Acheson Report). London: The Stationery Office, 1998.

2. Department of Health. Healthy lives, healthy people: our strategy for public health in England. London: The Stationery Office; 2010

3. Marmot M. Fair Society, Healthy Lives: The Marmot Review. 2010.

http://www.marmotreview.org/AssetLibrary/pdfs/Repo rts/FairSocietyHealthyLives.pdf (accessed 7 Feb 2011).

4. Anonymous. 'Claptrap' from the UK's Department of Health. Lancet 2010; 376(9753): 1617.

5. Black C. Working for a healthier tomorrow. Dame Carol Black's Review of the health of Britain's working age population. London: TSO, 2008.

6. Wakefield M, Loken B, Hornik R. Use of mass media campaigns to change health behaviour. Lancet 2010; 376(9748): 1261-1271.

7. LeCuyer N, Singhal S. Overhauling the US health care payment system. The McKinsey Quarterly. 2007; https://www.tipaaa.com/pdf/Overhauling\%20the\%20U S\%20Health\%20Care\%20Payment\%20SystemMcKinsey\%20Report.pdf (accessed 28 Jan 2011).

8. Hart JT. A new kind of doctor. J R Soc Med 1981; 74 (12): 871-883.

9. Whitehead M, Hanratty B, Popay J. NHS reform: untried remedies for misdiagnosed problems? Lancet 2010; 376: 1373-1375.

10. Stuckler D, Basu S, McKee M. Budget crises, health, and social welfare programmes. BMJ 2010; 340: c3311.

DOI: 10.3399/bjgp11X561122

\section{ADDRESS FOR CORRESPONDENCE}

\section{Steve Gillam}

Department of Public Health and Primary

Care, Institute of Public Health, University of Cambridge, Robinson Way, Cambridge CB2 2SR.

E-mail:sjg67@medschl.cam.ac.uk 